\title{
Research on the Relationship between Critical Thinking and Employee Innovation Behavior
}

\author{
Xiaoqing $\mathrm{Li}^{\mathrm{a}}$, Lu Ma ${ }^{\mathrm{b}}$ \\ School of Management, Guangxi University of Technology and Science, Liuzhou 545006, China \\ a771680275@qq.com, bmalu6655@163.com
}

\begin{abstract}
Keywords: Critical Thinking, Innovative Self-efficacy, Employee Innovation Behavior, Organizational Support.
\end{abstract}

\begin{abstract}
With the rise of critical thinking in the field of management, whether it has a role in promoting employee innovation behavior and what the transmission mechanism of this role has not yet been studied. According to social cognitive theory and social exchange theory, there is a close relationship between innovative self-efficacy and perceived organization support and critical thinking and employee innovation behavior. Therefore, this study to critical thinking as a former variable, perceived organization support as an adjustment variable to explore its influence on innovative selfefficacy and employee innovation behavior. With a hope to perfecting the relationship research between critical thinking and employee innovation behavior.
\end{abstract}

\section{Introduction}

The dynamic change of the external environment brings more challenges to the survival and development of the enterprise. Faced with these challenges, companies can only achieve sustainable competitive advantage through innovation. Enterprise innovation needs to consider the individual, team and organization of three levels of factors and their interaction. At the micro level, employee innovation behavior is the basis of enterprise innovation.

Individual behavior is dominated by the individual consciousness and perception. The same is true of the employee's innovation behavior in the organization. This perception including the perception of the ability and beliefs of fulfilling the task,which Bandera (1997) as a self-efficacy of individual employees. ${ }^{[1]}$ When this self-efficacy occurs in the field of innovation and combined with the theory of creativity, it becomes innovative self-efficacy, which is the belief that the individual can achieve the fruits of innovation (Tierney \& Farmer 2004). ${ }^{[2]}$ We can assume that employees with higher innovative self-efficacy are more aggressive and likely to generate innovative behavior. Employee innovation behavior is different from the general behavior, it requires the ability to propose appropriate questions and to give solutions, that is, to be critical thinking (Meyers 1986). ${ }^{[3]}$ Otherwise, if employees perceived that the organization is very supportive and caring for their work and life, whether he will make more creative behavior still need to study. Research on Critical thinking in management gradually attracted the attention of foreign scholars.

\section{Concept Definition}

\subsection{Critical Thinking.}

The definition of critical thinking can be divided into four stages, as shown in table 2-1.

\subsection{Employee Innovation Behavior.}

Employee Innovation Behavior is a rich connotation conception. Amabile (1996) argues that employee innovation behavior is a multistage process involving the creation and realization of creative ideas $^{[4]}$. Scott and Bruce (1994) argue that employee innovation behavior begins with the problem of individual identification, which in turn leads to innovative ideas and puts them into practice, ultimately transforming it into new product behavior ${ }^{[5]}$. Peng Jisheng (2010) argue that innovation is the result of new ideas and manifestations of innovative behavior for employees ${ }^{[6]}$. 
Generally speaking, these concepts are based on the innovation process or the results of the perspective of employee innovation behavior, which comes from the individual innovation awareness, and not subject to time and space constraints.

Table 2-1 Definitions of critical thinking at different times

\begin{tabular}{|c|c|c|}
\hline Time & Level & Representatives and Views \\
\hline Before the 1980s & Cognition and Skill & $\begin{array}{l}\text { Watson: Critical thinking is the combination of } \\
\text { attitudes, knowledge and skills ; }\end{array}$ \\
\hline $1980 \mathrm{~s}$ & $\begin{array}{l}\text { Thinking way, } \\
\text { Thinking process, } \\
\text { Reflection thinking }\end{array}$ & $\begin{array}{l}\text { Ennis(1987), Critical thinking is a reasonable, } \\
\text { introspective thinking that determines what to } \\
\text { believe or what. }\end{array}$ \\
\hline $1990 \mathrm{~s}$ & $\begin{array}{l}\text { Thinking content, } \\
\text { Metacognitive ability, } \\
\text { Thinking tendency }\end{array}$ & $\begin{array}{l}\text { Ruminski \& Hanks (1995): Face the problem, } \\
\text { find a solution and reasoning high-level thinking } \\
\text { ability and thinking. }\end{array}$ \\
\hline After 21 st century & $\begin{array}{l}\text { Standards and } \\
\text { Refinement }\end{array}$ & $\begin{array}{l}\text { Paul \& Elder(2008): Critical thinking is a self- } \\
\text { guided, self-disciplined, self-monitoring and } \\
\text { corrective thinking that follows strict standards } \\
\text { and flexible use. }\end{array}$ \\
\hline
\end{tabular}

\subsection{Innovative Self-Efficacy.}

The conception of self-efficacy originally proposed by social behaviorist Bandera refers to the individual's confidence in his ability to take on the task and have the ability to achieve the desired results, Self-efficacy has been associated with specific areas, specific tasks, and even specific issues since the concept was proposed. Self-efficacy for specific areas, specific tasks, and specific problems is more predictive of behavior. Tierney \& Farmer along the field of relevant self-efficacy research ideas, Combining Amabile's theory of creativity, the concept of "Innovative Self-efficacy" is proposed, which refers to the belief that the individual can achieve the result of innovation. The concept of "Innovation" mainly refers to whether employees have new and appropriate ideas and solutions in the course of their work, a concept that is endorsed by follow-up researchers.

\subsection{Perceived Organization Support.}

The eighties of the twentieth century, the American scholar Eisenberger and so put forward the conception of Perceived Organization Support (Referred to as POS), use to describe the overall sense that employees attach importance to their contribution to the organization, care about their welfare benefits $^{[7]}$. The theoretical basis of organizational support is the social exchange theory, which holds that the relationship between people is essentially a social exchange, which includes both material exchange and non-material exchange. When we get the positive treatment of others, we tend to tend to return positive treatment.

\section{A Summary Of Domestic And International Research}

\subsection{Research on the Influence of Critical Thinking on Employees' Innovation Behavior.}

Critical thinking is widely regarded as an important personality variable that determines individual behavior in recent years. Jiang Jing argues that critical thinking has an important role in promoting employee creativity. Feng Yan $(2012)^{[8]}$ think that innovative thinking ability is the core of innovation help to improve the individual's ability to innovate. Some scholar also believes that open mind and different views to take a tolerant attitude, they know that the process of innovation is full of a variety of uncertainties, but the process itself will promote the promotion of innovative behavior. King (1994) ${ }^{[9]}$ explores the content of critical thinking and finds that no matter what the specific meaning of critical thinking is, it is essential to the development of the organization and the employee. 


\subsection{Research on the Influence of Critical Thinking and Innovative Self- efficacy on Employee Innovation Behavior.}

An important personality trait of a critical thinking individual is open mind ${ }^{[10]}$, This means that individuals with critical thinking not only believe their own reasoning judgments, but also believeing others, thereby enhance the individual's sense of self-efficacy. Individuals with critical thinking tend to have an indomitable spirit of exploration for truth, Mainly in their own, to others, the traditional theory dare to question, deny and beyond, Face the difficulties dare to adhere to and process of innovation in the psychological energy.

Innovative self-efficacy and innovative behavior also have a close relationship. Tierney \& Farmer study found that innovative self-efficacy has a significant positive impact on individual innovation behavior, and that innovation self-efficacy is better than work efficiency in predicting individual's innovative behavior. Chang Qin and other research believe that innovative self-efficacy and individual innovation activities are closely related to the individual will affect the creative thinking and challenge the spirit, and ultimately affect the employee's innovative behavior and innovative performance ${ }^{[11]}$.

\subsection{Research on the Influence of Organizational Support and Innovative Self-efficacy.}

O'Driscoll and Randall argue that employees who are supported by the organization are more likely to feel obligated to care about the development of the organization, This sense of responsibility will make the staff full of confidence and full of hope, so as to stimulate the employee's sense of selfefficacy. Avolio's research shows that organizational support will directly affect positive physical and psychological outcomes and stimulate and promote the overall psychological potential of individuals ${ }^{[12]}$.

\section{Summary}

This study integrates social cognitive theory and social exchange theory tries to construct a moderated mediation model of critical thinking and employee innovation behavior. There are still some shortcomings in this study. First, the lack of scale selection. Most of the scales in this study are derived from foreign studies. Although this study has adapted the scale to a certain extent to suit the Chinese situation, it is still necessary to make more detailed changes to the Chinese culture. Secondly, this study only from the individual level of the employee, and the factors that affect the employee's innovation behavior from the organizational level, such as organizational atmosphere, leadership and so on still need to be considered. Further study should consider more influencing factors.

\section{Acknowledgements}

Innovation Project of Guangxi University of Science and Technology Graduate Education, NO:GKYC201611.

\section{References}

[1]. Bandura A. Self-efficacy: toward a unifying theory of behavioral change [J].Psychological Review, 1977, 84(02),191-215.

[2]. Tierney P. \& Farmer S. the Pygmalion process and employee creativity [J], Journal of Management,2004, 30 (3),413-432.

[3]. Meyers C. Teaching Students to Think Critically[M].San Francisco: Josses-Bass Press, 1986.

[4]. Amabile T M. Creativity and Innovation in Organization [M] .Boston: Harvard Business School, 1996.

[5]. Scott, S. G Bruce, R .A, "Determinants of Innovative Behavior :A Path Model of Individual Innovation in the Workplace", Academy of Management Journal,1994. 37(3) ,pp: 580-607.

[6]. Peng Jisheng et al. Effect of Organizational Ambience Perception on Employee Innovation Behavior-Mediating Effect Based on Knowledge Sharing Willingness [J] .Journal of Scientific Research Management, 2013, (05): 130-135. 
[7]. Eisenberger R, Huntington R, Hutchisom S, et al. Perceived Organizational Support [J]. Journal of Applied Psychology, 1986,71(2):500-507.

[8]. Feng Yan. Research on the Relationship between Critical Thinking and Innovation [J]. Journal of Yanshan University, 2012, (04): 22-25.

[9]. King, P. M. Kitchener, K. S. Developing Reflective Judgment: Understanding and Promoting Intellectual Growth and Critical Thinking in Adolescents and Adults, San Francisco: Jossey Bass Press, 1994.

[10]. Facione, P. A. The Delphi Report. Critical Thinking: A Statement of Expert Consensus for Purposes of Educational Assessment and Instruction. California: California Academic Press, 1990.

[11]. Qin Chang, etc. Management of self-efficacy and manager's attitude and performance of the relationship between the performance [J]. Peking University: Natural Science Edition, 2006, 42(2):276-280.

[12]. Avolio, B. J. Leadership Development in Balance: Born/Made. Mahwah, NJ: Lawrence Erlbaum, 2005: 431.

Author in brief:

Li Xiaoqing, postgraduate studying in Guangxi University of Science and Technology, mainly engaged in human resource management. E-mail: 771680275@qq.com. 